Krzysztof Koszela

Maciej Zaborowicz.

Instytut Inżynierii Biosystemów

Uniwersytet Przyrodniczy w Poznaniu

\title{
Modele neuronowe wspomagające prognozowanie cen pszenicy konsumpcyjnej na zdecentralizowanym rynku towarowym
}

\section{Streszczenie}

Celem pracy jest zbadanie możliwości wygenerowania i wykorzystania modeli neuronowych w predykcji najniższej oraz najwyższej dziennej ceny pszenicy konsumpcyjnej na rynku Forex. Dokonano analizy parametrów wejściowych i przygotowano zbiory uczące sieci neuronowych, tak by możliwe było wygenerowanie modeli neuronowych. Po wygenerowaniu sztucznych sieci neuronowych przeprowadzono analizę wrażliwości, a także przebudowano zbiór uczący, poszerzając go jednocześnie o dane niezbędne do prawidłowego prognozowania ceny.

Słowa kluczowe: sztuczne sieci neuronowe, prognozowanie cen, Forex, pszenica.

\section{Charakterystyka rynku Forex}

Rynek Forex (od ang. foreign exchange) to zdecentralizowany rynek towarowy OTC (over the counter), nieposiadający globalnej jednostki nadzorującej. Oparty jest na rynku walutowym, ale możliwy na nim jest również handel surowcami 
takimi, jak: metale szlachetne, ropa naftowa, gaz ziemny, kukurydza, kawa, soja, cukier i pszenica. 10\% rynku Forex stanowią instytucje finansowe, natomiast $90 \%$ - podmioty indywidualne [Galant i Dolan 2007]. Handel na rynku Forex odbywa się 24 godziny na dobę przez pięć dni w tygodniu. Dzienny obrót sięga 5 bln USD [Worrachate i Goodman 2012]. Według analityków gra na rynkach walutowych, ze względu na spekulantów, jest bardzo trudna. Rynek ten charakteryzuje się dużą płynnością i zmiennością kursów. Szacuje się, że ok. 82\% polskich inwestorów bezpowrotnie traci swoje środki [Dominiak 2012].

Charakterystyczną cechą tego rynku jest możliwość osiągania zysków kapitałowych zarówno na zwyżkach kursów, jak i na ich zniżkach. Pozycja długa (gra na zwyżkę) oznacza kupno np. buszla pszenicy konsumpcyjnej za odpowiednią ilość dolarów amerykańskich, przy czym kupujący liczy na wzrost kursu pszenicy i sprzedaż po cenie wyższej niż cena zakupu. Pozycja krótka (gra na zniżkę) to transakcja odwrotna, gdy gracz przewiduje obniżenie kursu pszenicy. Oznacza to, że pszenicę wymienia się na dolary amerykańskie, a gdy kurs się obniży, odkupuje się zadeklarowaną ilość pszenicy, uzyskując korzyść finansową [Matinez 2012]. Pozycja krótka oznacza sprzedaż instrumentu, którego tak naprawdę się nie posiada.

Ze względu na mechanizm lewarowania Forex jest interesujący dla potencjalnych graczy. Lewarowanie to mechanizm dźwigni finansowej, który pozwala kontrolować pozycję rynkową o określonej wielkości, zależną od wysokości depozytu złożonego na rachunku brokerskim. Podstawową jednostką rozliczeniową jest 1 lot, czyli 100 tys. jednostek waluty bądź surowca. Uczestnik rynku powinien złożyć depozyt umożliwiający zawieranie transakcji. Dzięki dźwigni finansowej gracze rynku Forex składają znacznie mniejsze depozyty. Wśród polskich brokerów jest to średnio 2 tys. zł. Brokerzy oferują wiele możliwości użycia dźwigni finansowej, jednymi z najbardziej popularnych są 100:1, 50:1, 10:1. Dźwignia 100:1 oznacza, że posiadając 5 tys. dolarów amerykańskich, gracz może kontrolować pozycję o wartości 500 tys. dolarów. Należy pamiętać, że lewarowanie niesie ze sobą bardzo wysokie zyski, ale też potencjalne straty związane nawet $\mathrm{z}$ niewielkimi wahaniami kursu [Kochan 2009].

\section{Analiza rynku Forex}

Aby przewidzieć kurs na rynku walutowym, należy dokonać analizy fundamentalnej i (lub) analizy technicznej [Galant i Dolan 2007]. Analiza fundamentalna to podstawowe dane ekonomiczne dotyczące raportów o danych gospodarczych, poziomach dochodowości inwestycji, polityce monetarnej, międzynarodowej wymianie towarowej oraz poziomie inwestycji zagranicznych 
kraju, którego wartość waluty rozpatrujemy [Karpuś i Węsławski 2009]. Analiza techniczna z kolei jest wnioskowaniem o kursie i trendzie na podstawie wykresów notowań w różnych interwałach czasu. Analizę techniczną wspomagają matematyczne modele możliwości zachowania kursów walut, obliczenia impetu, średnich kroczących i innych tym podobnych parametrów [Pring 2010].

Pomimo bardzo dużej ilości danych oraz dostępności środków technicznych nie zawsze możliwa jest prognoza kierunku kursu pary walutowej bądź surowca. Wielu analityków uważa, że niezbędny jest również instynkt gracza oraz psychologiczne podejście do zachowań rynku [Galant i Dolan 2007]. Z tego powodu powszechnie stosuje się symulatory scenariuszy gry oraz programy wspomagające decyzje inwestycyjne.

\section{Modelowanie neuronowe}

Jednym z narzędzi wykorzystywanych do predykcji kursów jest modelowanie neuronowe ze względu na własności, które pozwalają uważać je za właściwe narzędzie w procesie analizy i prognozowania kursów [Domaradzki 2007]. Celem modelowania neuronowego jest wspomaganie racjonalnego prognozowania pożądanych wartości kursów i wskaźników w odniesieniu do wartości rzeczywistych. Jakość prognozy wygenerowanej przez model sztucznej sieci neuronowej zależy od tzw. matematycznej ścisłości modelu i wiernego odzwierciedlenia realiów [Wyrozumski 2005].

Działanie modelu neuronowego opiera się na zasadach podobnych do sposobu działania ludzkiego mózgu. Sztuczny neuron potrzebuje pewnej ilości danych, które będą uszeregowane w odpowiedni sposób. Są to tzw. sygnały wejściowe, które przekazywane do neuronów warstwy ukrytej sztucznej sieci neuronowej są przetwarzane przy użyciu formuł matematycznych. Kolejnym krokiem jest przekazanie przetworzonych informacji do ostatniej warstwy wyjściowej, która zwraca ostateczny wynik [Zieliński 2010]. Kluczowym etapem generowania modeli neuronowych, w tym modeli prognostycznych, jest odpowiednie skonstruowanie zbioru uczącego, czyli skompletowanie i uszeregowanie danych uczących, na podstawie których model stara się odkryć i zapamiętać występujące prawidłowości. Od właściwego doboru wektora wejściowego zależą możliwości prognostyczne generowanego modelu.

Istnieje wiele czynników rynku finansowego mających wpływ na kurs danego waloru. Można do nich zaliczyć wskaźniki techniczne, dane opóźnione, wartości indeksów z rynków zagranicznych oraz inne wskaźniki ekonomiczne. Odpowiedni dobór zmiennych stanowi trudność. Istotny jest wybór parametrów skorelowanych 
ze zmienną prognozowaną, a jednocześnie parametrów najmniej skorelowanych między sobą [Domaradzki 2007].

Proces modelowania neuronowego jest kilkuetapowy. Rozpoczyna się od zbioru danych dotyczących danego zagadnienia. W przypadku giełdy i instrumentów finansowych są to wszystkie parametry opisujące dany indeks. We wstępnym etapie trudno jest określić, która architektura modelu neuronowego będzie w odpowiedni sposób prognozowała zadane parametry i tym samym spełniała oczekiwania użytkownika. Dlatego też w procesie modelowania neuronowego wykorzystuje się symulatory sztucznych sieci neuronowych, które w szybki i skuteczny sposób wspomagają pracę, zwalniając użytkowników ze żmudnego procesu generowania kodu i odnajdowania zależności pomiędzy analizowanymi danymi.

Modelowanie neuronowe stosuje się tam, gdzie klasyczne metody programowania i analizy danych nie przyniosły oczekiwanych rezultatów oraz w momencie zbyt dużej ilości danych możliwych do przeanalizowania przez człowieka. Rynki finansowe to obszar dynamiczny. Ilość informacji, jaka dostarczana jest na rynek w ciągu kilkudziesięciu sekund, potrafi zupełnie rozmyć obraz rzeczywistości, paraliżując użytkownika przed podjęciem racjonalnej decyzji. Ze względu na tak dużą ilość danych stosuje się programy wspomagające decyzje, w tym programy wyposażone w moduły sieci neuronowych [Frydrychowicz i Szymańska 2008].

Najczęściej modele prognostyczne stosuje się na giełdach papierów wartościowych, gdzie emocje graczy nie są tak silne, a wskaźniki rynku bardziej przewidywalne. Na polskim rynku najczęściej próbuje się przewidzieć wartość indeksu WIG20, dwudziestu największych giełdowych spółek, na podstawie których ocenia się bieżący stan gospodarki. W zagadnieniach tego typu najczęściej stosuje się perceptrony wielowarstwowe, które z dokładnością do ok. $2 \%$ potrafią prognozować wartość tego indeksu. Zatem można je uznać za poprawnie działające narzędzia, które mogą wspomagać proces podejmowania decyzji inwestora. Na rynkach finansowych występują sytuacje trudne do przewidzenia. Mają one charakter silnie nieliniowy, dlatego też do rozwiązywania tego typu problemów najczęściej stosuje się sieci o radialnych funkcjach bazowych RBF [Domaradzki 2007]. Poza predykcją kursów giełdowych modelowanie neuronowe stosuje się do analizy ryzyka kredytowego, analizy leasingowej, wyboru strategii inwestycyjnej oraz wykrywania nadużyć finansowych [Frydrychowicz i Szymańska 2008].

\section{Cel i realizacja badań}

Celem badań było sprawdzenie możliwości wygenerowania modelu neuronowego wspomagającego prognozowanie dziennego najwyższego i najniższego kursu kupna-sprzedaży pszenicy konsumpcyjnej na rynku Forex. 
Ze względu na swoje właściwości, pszenica, oprócz jęczmienia, jest najstarszym zbożem chlebowym, po ryżu i kukurydzy zajmuje trzecie miejsce w światowej produkcji zbóż. Rocznie na świecie produkuje się jej $690 \mathrm{mln}$ ton, a od ilości jej produkcji i ceny zależy cena mąki, dalszego surowca w produkcji żywności.

Cel pracy zrealizowano w kilku etapach. Pierwszym krokiem było pozyskanie dziennych kursów kupna-sprzedaży pszenicy konsumpcyjnej w latach 2004-2012. Dane pozyskano z Centrum Historii, ogólnodostępnej platformy transakcyjnej BossaFX. Dane zaimportowano do postaci pliku *.csv. Zawierały one: czas (datę notowania), otwarcie (kurs otwarcia), High (najwyższą dzienną wartość), Low (najniższą dzienną wartość), zamknięcie (kurs zamknięcia) oraz wolumen. Pozyskane dane zostały skonwertowane do postaci zbiorów uczących symulatorów sztucznych sieci neuronowych w autorskim programie Forex Project. Umożliwił on odpowiednie uszeregowanie informacji, jak też ich uzupełnienie o dzień tygodnia, dzień roku oraz kwartał, w którym odbywały się notowania. Podanie tych informacji mogło mieć znaczący wpływ na proces uczenia modelu neuronowego oraz późniejszą predykcję wartości kursu. Decyzję tę podjęto po analizie cykliczności wahań kursów w ostatnich dziesięciu latach notowań.

Przygotowany zbiór uczący poddano analizie oraz generowaniu modeli neuronowych w pakiecie STATISTICA. W początkowej fazie badań podczas projektowania użyto funkcji Automatycznego projektanta sieci. Rezultatem przeprowadzonej pierwszej symulacji było wygenerowanie modelu neuronowego, który ze względu na swoje parametry nie spełniał wymagań jakościowych. Cechował się zbyt dużym błędem działania sieci oraz zbyt niską jej jakością. Wyniki procesu uczenia sieci wskazywały na jej przeuczenie oraz prognozowanie wartości kursu „z pamięci”. Dodatkowo można było zaobserwować długi i żmudny proces modelowania, który wynosił ok. 8 godzin. W związku z powyższym nie było możliwości użycia wygenerowanego modelu na realnym rynku finansowym. W następnym etapie postanowiono sprawdzić, czy zwiększenie lub pomniejszenie liczby przypadków uczących zbioru uczącego wpłynie na proces generowania odpowiedniej jakości modeli neuronowych. Zwiększanie ilości danych nie przyniosło pożądanego rezultatu. Ze względu na zbyt dużą ich ilość (początkowo były to 2073 przypadki uczące), uczenie się sieci na pamięć oraz zbyt długi czas modelowania postanowiono ograniczyć zbiór uczący do lat 2009-2012 (843 przypadki uczące). Tak przygotowany zbiór poddano ponownej analizie w symulatorze STATISTICA. Zaobserwowano, że proces generowania modelu neuronowego znacząco uległ skróceniu (do ok. 6 min). Wytworzony model RBF 5:12-33-1:1 wygenerował poprawną prognozę ceny w $42 \%$ przypadków. Taki wynik nadal był niezadowalający. Dlatego postanowiono przeprowadzić ponowną analizę rynku pod kątem czynników mających wpływ na kurs pszenicy konsumpcyjnej. Na tej podstawie poszerzono zbiór uczący o zmienne dotyczące ropy naftowej 
(crude oil), kukurydzy i kursu pary walutowej EUR/USD, które uwzględniały kurs otwarcia, kurs zamknięcia, najniższy i najwyższy dzienny kurs oraz wolumen z analogicznego okresu notowań pszenicy konsumpcyjnej. Tak rozbudowany zbiór uczący zawierał 25 zmiennych. Ponowne wygenerowanie modelu neuronowego RBF 13:13-21-1:1 pozwoliło zaobserwować spadek jakości prognozowania ceny do 40\%. Kolejnym krokiem była przebudowa zbioru uczącego. „Przesunięto” dane o jeden wiersz wyżej (rys. 1), tak aby dane opisujące datę, dzień tygodnia, dzień roku oraz cenę minimalną i maksymalną były opisywane parametrami z dnia poprzedniego.

Przekonstruowanie zbioru uczącego dało możliwość wygenerowania liniowej sieci neuronowej 13:13-1:1 o skuteczności prognozowania 56\%. Na tym etapie postanowiono zrezygnować z funkcji Automatycznego projektanta sieci. Krok ten podyktowany był brakiem możliwości zwiększenia dokładności prognozy w kolejnych iteracjach uczenia sieci. Skorzystano z Projektanta sieci użytkownika, co pozwoliło na wygenerowanie nowej sieci RBF 24:24-26-1:1 o znacznie wyższej wartości jakości prognozowania na poziomie $88 \%$. Ostatnim krokiem, który mógł pozwolić na zwiększenie dokładności prognozy, była zmiana ilości neuronów warstwy ukrytej. Postanowiono zredukować liczbę neuronów. Efektem redukcji była minimalizacja błędu prognozy oraz zdolność predykcji ceny na poziomie 95\%. Wygenerowany model neuronowy pozwalał prognozować najniższą cenę pszenicy. Była to sieć o radialnych funkcjach bazowych RBF 24:24-15-1:1 (rys. 2). Dane wejściowe sieci (rys. 3) to: data, dzień tygodnia, dzień roku, kwartał oraz parametry dnia poprzedniego opisujące najwyższą oraz najniższą cenę, kurs otwarcia i zamknięcia, a także wolumen pszenicy, ropy naftowej, kukurydzy oraz pary walutowej EUR/USD. Na tej podstawie wygenerowano model pozwalający na predykcję najwyższej dziennej ceny pszenicy konsumpcyjnej. Najlepszy z całego wygenerowanego zbioru sieci okazał się model RBF 15:15-10-1:1, który do swojego działania używa następujących zmiennych: data, dzień roku, dzień tygodnia, kwartał, kurs otwarcia, zamknięcia i najwyższy dzienny kurs pszenicy wraz z wolumenem, a także kurs otwarcia, zamknięcia i najwyższy dzienny kurs kukurydzy i dzienny wolumen pary walutowej EUR/USD.

W czasie badań szczególny nacisk położono na poprawność działania i dokładność wygenerowanych modeli. Założono, że należy wygenerować dwie sieci neuronowe, z których jedna pozwoliłaby na predykcję najniższego dziennego kursu, a druga najwyższego dziennego kursu. W efekcie powstały dwa modele neuronowe o 24 i 15 zmiennych wejściowych i jednym wyjściu.

Sieć neuronową uczono trzema algorytmami: SS (SubSample) - próbkowaniem, EX (explicit) - z określeniem odchylenia neuronu radialnego oraz PI (pseudoinwersji) - optymalizacja liniowa najmniejszych kwadratów. 


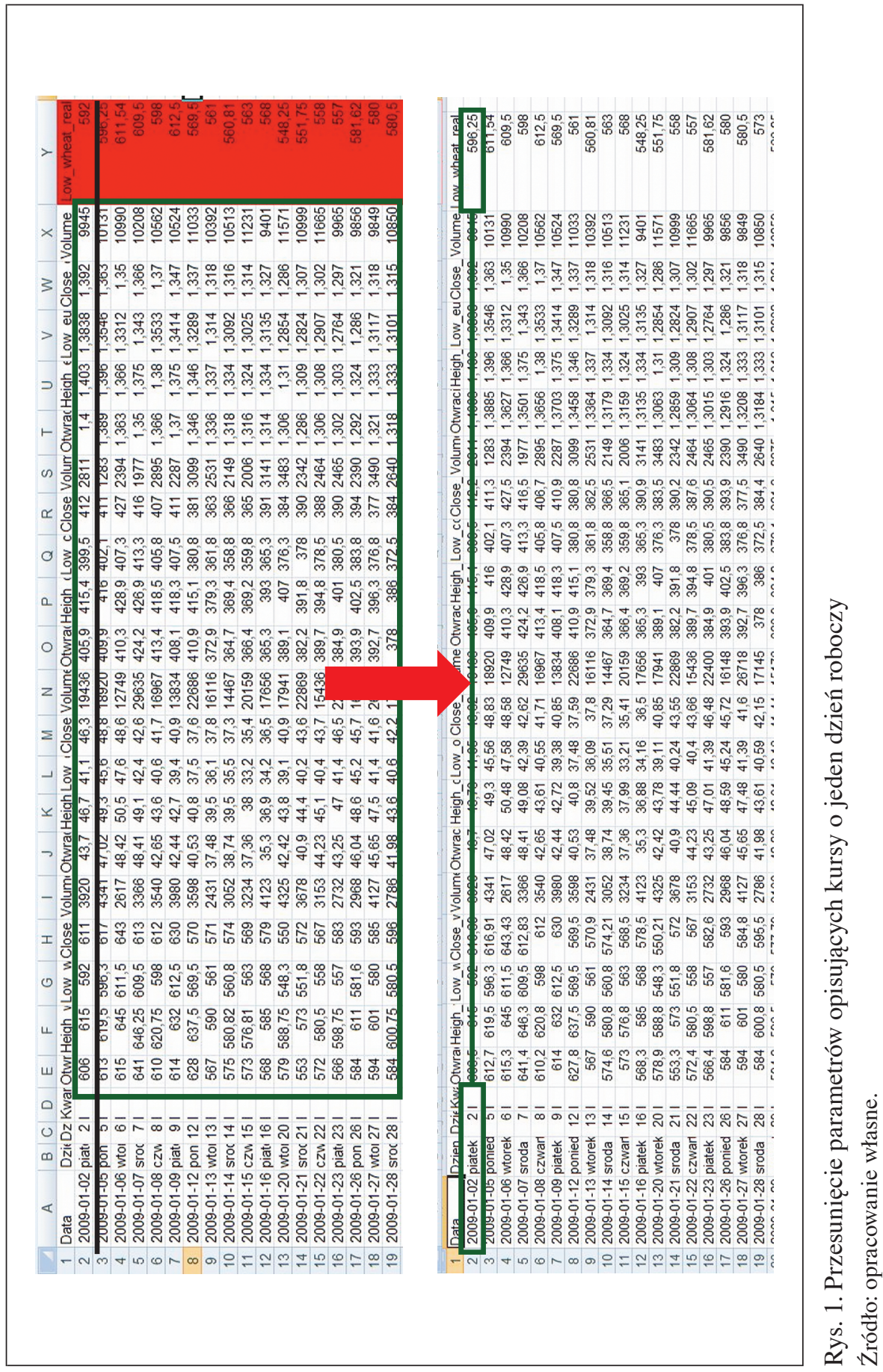




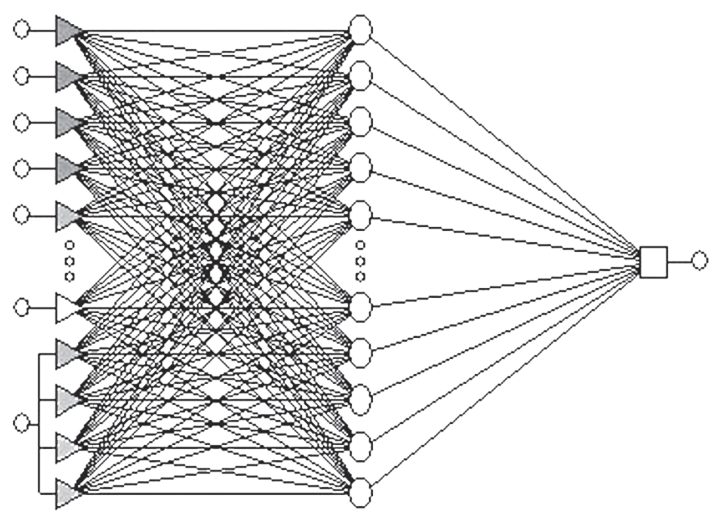

Rys. 2. Sieć RBF 24:24-15-1:1

Źródło: opracowanie własne.

\begin{tabular}{|c|c|c|c|c|c|c|c|c|c|c|c|c|c|c|c|}
\hline \multicolumn{14}{|c|}{ 回 Danei pszenica_kukurydza_ropa_eurusd (25 zmn. * 343 prz.) } & \multicolumn{2}{|c|}{ 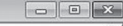 } \\
\hline & & & & & & & & & & & & & & & \\
\hline & $\begin{array}{c}1 \\
\text { Data }\end{array}$ & ${ }^{2}$ tyien tyg & Jzien_roku & $\begin{array}{c}4 \\
\text { Kwartal }\end{array}$ & $\begin{array}{c}5 \\
\text { Jtwracie, wheat }\end{array}$ & $\begin{array}{c}6 \\
\text { teigh_wheat }\end{array}$ & $\begin{array}{c}7 \\
\text {. Ow_wheat }\end{array}$ & Zlose_wheat & Iolume wheat & $\begin{array}{c}10 \\
\text { Jtwracie_oil }\end{array}$ & $\begin{array}{c}11 \\
\text { Heigh_oil }\end{array}$ & $\begin{array}{c}12 \\
\text { Low_oil }\end{array}$ & $\begin{array}{c}13 \\
\text { Close_oil }\end{array}$ & $\begin{array}{c}14 \\
\text { Jolume_oil }\end{array}$ & \\
\hline 1 & $2009-01-0$ & piatek & 2 & & 606,46 & $6 \quad 615$ & $5 \quad 592$ & $2 \quad 610,69$ & 3920 & 43,7 & 76,73 & 341,05 & 46,32 & $2 \quad 19436$ & \\
\hline & $2309-01-0$ & poniedzial & 5 & & 612,66 & 619.5 & 596,25 & 616,91 & 4341 & 47,02 & 49,3 & 45,56 & 48.83 & 18920 & \\
\hline & $2309-01-0$ & 5 whorek & 6 & & 615,25 & 645 & 611,54 & 643,43 & 2617 & 48,42 & 50,48 & 47,58 & 48,58 & 12749 & \\
\hline & $2009-01-0$ & sroda & 7 & & 641,36 & 646,25 & 609,5 & 612,83 & 3366 & 48,41 & 49,08 & 42,39 & 42,62 & 29635 & \\
\hline & $2309-01-0$ & czwartek & 8 & & 610,19 & 620,75 & 598 & 612 & 3540 & 42,65 & 43,61 & 40,55 & 41,71 & 16967 & \\
\hline & $2309-01-0$ & piatek & 9 & & 614,01 & 632 & 612,5 & 630 & 3980 & 42,44 & 42,72 & 39,38 & 40,85 & 13834 & \\
\hline & $2.09-01-1$ & 1 poniedzial & 12 & & 627,76 & 637.5 & 569.5 & 569.5 & 3598 & 40,53 & 40.8 & 37.48 & 37.59 & 22686 & \\
\hline & $2309-01-1$ & 1 whorek & 13 & & 566,98 & 590 & 561 & 570,9 & 2431 & 37,48 & 39,52 & 36,09 & 37,8 & 16116 & \\
\hline 9 & $2309-01-1$ & 1 sroda & 14 & & 574,62 & 580,82 & 560,81 & 574,21 & 3052 & 38,74 & 39,45 & 35,51 & 37,29 & 14467 & \\
\hline 10 & 2J09-01-1 & 1 czwartek & 15 & & 572,98 & 576,81 & 563 & 568,5 & 3234 & 37,36 & 37.99 & 33,21 & 35,41 & 20159 & \\
\hline 11 & 2309-01-1 & 1 piatek & 16 & & 568,27 & 585 & 568 & 578,5 & 4123 & 35,3 & 36,88 & 34,16 & 36,5 & 17656 & \\
\hline 12 & $2309-01-2$ & 2 whorek & 20 & & 578.91 & 588,75 & 548.25 & 550.21 & 4325 & 42.42 & 43.78 & 39.11 & 40.85 & 17941 & \\
\hline 13 & $2509-01-2$ & 2 sroda & 21 & & 553,31 & 573 & 551,75 & 572 & 3678 & 40,9 & 44,44 & 40,24 & 43,55 & 22869 & \\
\hline 14 & 2309-01-2 & 2 czwartek & 22 & & 572,43 & 580,5 & 558 & 567 & 3153 & 44,23 & 45,09 & 40,4 & 43,66 & 15436 & \\
\hline 15 & 2.309-01-2 & piatek & 23 & & 566,36 & 598,75 & 557 & 582,6 & 2732 & 43,25 & 47,01 & 41.39 & 46,48 & 22400 & \\
\hline 16 & 2J09-01-2 & 2 poniedzial & 26 & & 583,96 & 611 & 581,62 & 593 & 2968 & 46,04 & 48,59 & 45,24 & 45,72 & 16148 & \\
\hline 17 & 2J09-01-2 & 2 whorek & 27 & & 593.96 & 601 & 580 & 584,8 & 4127 & 45,65 & 47,48 & 41,39 & 41,6 & 26718 & \\
\hline 18 & $2309-01-2$ & sroda & 28 & & 583,97 & 600,75 & 580,5 & 595,5 & 2786 & 41,98 & 43,61 & 40,59 & 42,15 & 17145 & \\
\hline & |2509-01-2 & 2 czwartek & 29 & & 594,76 & 596,5 & 573 & 577,79 & 3133 & 42,23 & 42,31 & 40,16 & 41,44 & 15176 & \\
\hline पर & & & & & & & & & & & & & & & \\
\hline
\end{tabular}

Rys. 3. Dane służące do wygenerowania SSN

Źródło: opracowanie własne w programie STATISTICA.

Wygenerowane modele poddano weryfikacji w warunkach rzeczywistych. Podając odpowiednie zmienne, wytworzone sieci prognozowały wartości minimalne i maksymalne kursu na następny dzień roboczy (4.05.2012) - rys. 4. 


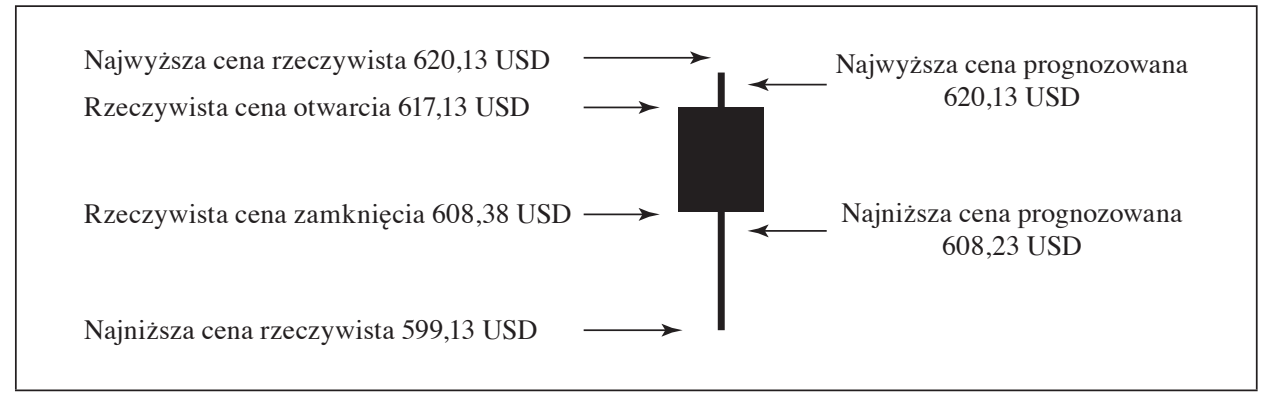

Rys. 4. Ceny rzeczywiste a prognozowane na dzień 4.05.2012 r.

Źródło: opracowanie własne.

Tabela 1. Zestawienie wartości rzeczywistych i prognozowanych (USD)

\begin{tabular}{|l|c|c|c|c|}
\hline \multirow{2}{*}{ Wyszczególnienie } & \multicolumn{2}{|c|}{ Najniższa cena } & \multicolumn{2}{c|}{ Najwyższa cena } \\
\cline { 2 - 5 } & rzeczywista & prognozowana & rzeczywista & prognozowana \\
\hline Cena & 599,13 & 608,23 & 620,13 & 618,20 \\
\hline Różnica & \multicolumn{2}{|c|}{9,10} & \multicolumn{2}{c|}{1,93} \\
\hline Błąd & \multicolumn{2}{|c|}{$1,52 \%$} & \multicolumn{2}{c|}{$0,47 \%$} \\
\hline
\end{tabular}

Źródło: opracowanie własne.

Zestawienie wartości rzeczywistych i prognozowanych przestawia tabela 1.

\section{Podsumowanie}

Ze względu na złożoność zagadnienia prognozowania cen zbóż w pracy przedstawiono możliwość użycia modelowania neuronowego. Efektem przeprowadzonych badań jest wygenerowanie dwóch modeli neuronowych RBF prognozujących dzienną najwyższą i najniższą wartość pszenicy konsumpcyjnej. Powstałe sieci o radialnych funkcjach bazowych świadczą o silnie nieliniowym charakterze zagadnienia. Błąd prognozowania wynosi od $0,47 \%$ do $1,52 \%$, a prognozę modelu neuronowego sprawdzono w warunkach rzeczywistych.

Przedstawione modele neuronowe charakteryzują się najlepszymi parametrami dotyczącymi jakości na tle innych wygenerowanych sieci. W pracy udowodniono, że zbyt duża liczba przypadków uczących znacznie wydłuża proces generowania modelu neuronowego oraz skutkuje ,uczeniem się sieci na pamięć”, co jest zjawiskiem niekorzystnym. Redukcja przypadków uczących, a następnie zwiększenie liczby zmiennych spowodowało podniesienie poziomu jakości modelu neuronowego. 
Na podstawie przeprowadzonych badań można sformułować następujące wnioski:

1) możliwe jest wygenerowanie modelu neuronowego wspomagającego prognozowanie dziennego kursu kupna-sprzedaży pszenicy. Jest to sieć RBF 24:24-15-1:1 oraz RBF 15:15-10-1:1, co sugeruje nieliniowy charakter zagadnienia;

2) po przeprowadzeniu analizy wrażliwości stwierdzono, że czynnikami mającymi dominujący wpływ na kurs pszenicy są wartości dotyczące notowań ropy naftowej, kukurydzy oraz pary walutowej EUR/USD.

\section{Literatura}

Galant M., Dolan M. [2007], Currency Trading for Dummies, Wiley Publishing, Hoboken. Worrachate A., Goodman D. [2012], Currency Trading at \$5 Trillion a Day Surpassed Pre-Lehman High, BIS Says, Bloomberg.

Dominiak J. [2012], Forex urywa ręce, Wyborcza.biz (data dostępu: 10.11.2012).

Domaradzki R. [2007], Zastosowanie sieci neuronowych do wspomagania decyzji inwestycyjnych, Praca doktorska, Akademia Górniczo-Hutnicza w Krakowie, Kraków.

Frydrychowicz W., Szymańska K. [2008], Zagadnienie sztucznych sieci neuronowych $w$ dynamicznych procesach niestandardowej ekonomii, Scientific Bulletin of Chełm Section of Mathematics and Computer Sience, $\mathrm{nr} 1$.

Karpuś P., Węsławski J. [2009], Rynek finansowy w erze zawirowań, UMCS w Lublinie, Lublin.

Pring M. [2010], Analiza techniczna dla inwestorów krótkoterminowych, Grube Ryby.

Matinez J. [2012], 10 fundamentalnych zasad na rynku Forex. Strategie osiagania zysku, Onepress.

Kochan K. [2009], Forex w praktyce. Vademecum inwestora walutowego, Onepress.

Wyrozumski T. [2005], Sieci neuronowe a energetyka - prawdy i mity o prognozowaniu [w:] Rynek energii elektrycznej: bezpieczeństwo energetyczne Polski w strukturze Unii Europejskiej, Materiały XI Konferencji Naukowo-Technicznej, t. II, Wydawnictwo Politechniki Lubelskiej, Lublin.

Zieliński G. [2010], Wykorzystanie sztucznych sieci neuronowych do prognozowania upadłości przedsiębiorstw, Wyższa Szkoła Zarządzania i Administracji w Zamościu, Publikacje Koła Metod Sztucznej Inteligencji, http://student.wszia.edu.pl/ msi/?m=pu (data dostępu: 10.05.2012).

\section{Neural Models for Predicting the Prices of Consumption Wheat on a Decentralised Commodity Market}

The aim of the study was to investigate the possibility of generating and using neural models for predicting the lowest and highest daily rates of consumption wheat in the Forex market. Input parameters and prepared learning sets of neural network are analysed with a view to generating neural models. After the artificial neural networks were generated, a sensitivity analysis was done and the learning set rebuilt. The set data required to properly forecast prices were added to the new training.

Keywords: artificial neural networks, forecasting prices, Forex, wheat. 